\title{
人工智能: 天使还是魔鬼?
}

\author{
谭铁牛，孙哲南，张兆翔* \\ 中国科学院自动化研究所, 北京 100190 \\ * 通信作者. E-mail: zhaoxiang.zhang@ia.ac.cn \\ 收稿日期: 2018-05-31；接受日期: 2018-08-22；网络出版日期: 2018-09-07
}

摘要 随着大数据的兴起与计算资源的丰富, 人工智能在诸多应用领域取得了显著突破, 成为了世 界各国竞相争先的战略制高点. 与此同时, 人工智能的社会影响日益突出,得到广泛关注的同时也备 受争议. 本文从宏观视角概览人工智能的基本概念、发展历程、发展现状和未来趋势, 试图揭示人工 智能的真实面貌和发展规律, 致力于引导全社会对人工智能技术的正确认知, 并倡议在人工智能发 展中应未雨绸缪、形成合力, 确保人工智能的正面效应与健康发展, 保障人工智能始终造福于人类.

关键词人工智能发展历程, 人工智能发展现状, 人工智能发展趋势, 法律法规, 社会伦理

\section{1 引言}

人工智能是近些年最受关注同时也富有争议的科技领域之一. 任何高科技都是一把双刃剑, 人工 智能也不例外，一方面 “天使派” 认为, 人工智能领域的科技创新和成果应用取得重大突破, 有望引领 新一轮技术和产业革命, 对社会、经济、军事等领域将产生变革性影响，在制造、交通、教育、医疗、 服务等方面可以造福人类; 另一方面 “魔鬼派” 认为, 人工智能是人类的重大威胁, 甚至比核武器还危 险. 2018 年 2 月 21 日, 牛津大学、剑桥大学和 OpenAI 公司等 14 家机构共同发布《人工智能的恶意 使用: 预测、预防和缓解》报告 ${ }^{[1]}$, 指出人工智能可能给人类社会带来数字安全、物理安全和政治安全 等潜在威胁, 并给出了一些建议以减少风险.

为了客观认识人工智能的本质内涵和来龙去脉, 本文试图通过介绍人工智能的基本概念、发展历 程、发展现状和未来趋势, 揭示人工智能的真实面貌.

\section{2 人工智能的基本概念和发展历程}

1956 年夏, 麦卡锡 (McCarthy)、明斯基 (Minsky)、罗切斯特 (Rochester) 和香农 (Shannon) 等科 学家在美国达特茅斯学院 (Dartmouth College) 开会研讨 “如何用机器模拟人的智能”, 首次提出 “人

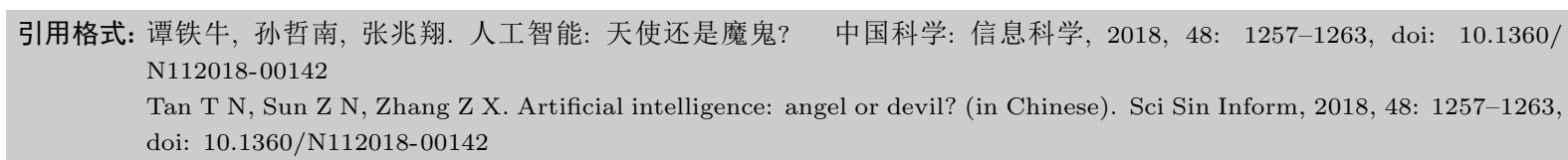


工智能” 这一概念, 标志着人工智能学科的诞生. 人工智能的目标是模拟、延伸和扩展人类智能, 探寻 智能本质, 发展类人智能机器.

人工智能充满未知的探索道路曲折起伏, 如何描述 1956 年以来 60 余年的人工智能发展历程, 学 术界可谓仁者见仁、智者见智. 我们将人工智能 60 余年的发展历程划分为以下 6 个阶段:

(1) 起步发展期: 1956 年 20 世纪 60 年代初. 人工智能概念在 1956 年首次被提出后, 相继取得 了一批令人瞩目的研究成果, 如机器定理证明、跳棋程序、LISP 表处理语言等, 掀起了人工智能发展 的第一个高潮.

(2) 反思发展期: 60 年代 $~ 70$ 年代初. 人工智能发展初期的突破性进展大大提升了人们对人工智 能的期望, 人们开始尝试更具挑战性的人工智能任务. 然而, 接二连三的失败和预期目标的落空 (例如 无法机器证明两个连续函数之和还是连续函数, 机器翻译闹出笑话等), 使人工智能的发展走入了低谷.

(3) 应用发展期: 70 年代初 80 年代中. 20 世纪 70 年代出现的各类专家系统, 实现了人工智能 从理论研究走向实际应用的重大转变. 随着一般思维规律探讨到专门知识运用的重大突破, 人工智能 走入了应用发展的新高潮.

(4) 低迷发展期: 80 年代中 90 年代中. 随着人工智能的应用规模不断扩大, 专家系统存在的应 用领域狭窄、缺乏常识性知识、知识获取困难、推理方法单一、缺乏分布式功能、难以与现有数据库 兼容等问题逐渐暴露出来.

(5) 稳步发展期: 90 年代中 2010 年. 由于网络技术特别是互联网技术的发展, 信息与数据的汇 聚不断加速, 互联网应用的不断普及加速了人工智能的创新研究, 促使人工智能技术进一步走向实用 化. 1997 年 IBM 深蓝超级计算机战胜了国际象棋世界冠军卡斯帕罗夫 (Garry Kasparo), 2008 年 IBM 提出 “智慧地球” 的概念, 这些都是这一时期的标志性事件.

(6) 蓬勃发展期: 2011 年至今. 随着大数据、云计算、互联网、物联网等信息技术的发展, 泛在感 知数据和 GPU 等计算平台推动以深度神经网络为代表的人工智能技术飞速发展, 大幅跨越科学与应 用之间的 “技术鸿沟”, 图像分类、语音识别、知识问答、人机对弯、无人驾驶等具有广阔应用前景的 人工智能技术突破了从 “不能用、不好用” 到 “可以用” 的技术瓶颈, 人工智能发展进入爆发式增长的 红利期.

\section{3 人工智能发展现状}

人工智能经过 60 多年的发展, 理论、技术和应用都取得了重要突破, 已成为推动新一轮科技和产 业革命的驱动力, 深刻影响世界经济、政治、军事和社会发展, 日益得到了世界各主要国家政府部门、 产业界和学术界的高度关注.

(1) 专用人工智能取得重要突破, 但是人工智能总体发展水平仍处于起步阶段. 从可应用性看, 人 工智能大体可分为专用人工智能和通用人工智能. 面向特定领域的人工智能技术 (即专用人工智能) 由于任务单一、应用背景需求明确、领域知识积累深厚、建模计算简单可行, 因此形成了人工智能领 域的单点突破, 在局部智能水平的单项测试中可以超越人类智能. 人工智能的近期进展主要集中在专 用智能领域, 例如 AlphaGo 在围棋比赛中战胜人类冠军李世石和柯洁 ${ }^{[2]}$, 人工智能程序在 ImageNet 图像识别 [3] 和 LFW 人脸识别中达到了超越人类的水平 ${ }^{[4]}$, 微软语音识别系统 $5.1 \%$ 的错误率比肩专 业速记员 ${ }^{[5]}, 2017$ 年斯坦福大学 Nature 的论文工作诊断皮肤癌达专家水平 [6].

人的大脑是一个通用的智能系统, 能举一反三、融会贯通, 可处理视觉、听觉、判断、推理、学习、 思考、规划、设计等各类问题, 可谓 “一脑万用”. 真正意义上完备的人工智能系统应该是一个通用的 
智能系统. 通用人工智能研究与应用刚刚起步, 依然任重道远.

人工智能系统的能力维度可分为信息感知 (perceiving)、机器学习 (learning)、概念抽象 (abstracting) 和规划决策 (reasoning). 目前人工智能系统在信息感知和机器学习方面进展显著, 但是在概念抽 象和规划决策方面能力还很薄弱. 总体上看, 目前的人工智能系统可谓有智能没智慧、有智商没情商、 会计算不会 “算计”、有专才无通才. 人工智能还有很多不能.

(2) 统计学习成为人工智能走向实用的理论基础. 近些年来, 深度学习、强化学习、对抗学习等 统计机器学习理论在计算机视觉、语音识别、自然语言理解、人机博弯等方向取得显著成果. 例如 通过深度神经网络的应用创新, 国际计算机视觉竞赛 ImageNet 图像分类的 Top 5 误差率从 2012 年 的 $16 \%{ }^{[7]}$ 降到了 2017 年的 $3 \%$ 左右 ${ }^{[3]}$, 在人机博亦方面, Nature 在 2016 和 2017 年分别发表了 AlphaGo ${ }^{[2]}$ 和 AlphaGo Zero ${ }^{[8]}$ 的工作, 其中 AlphaGo Zero 不依赖人类知识, 通过强化学习算法完胜 AlphaGo, 探索了特定应用中不依赖外部数据和知识的人工智能技术发展新路线.

(3) 人工智能技术生态建设备受重视. 人工智能技术生态包括数据平台、开源算法、计算芯片、基 础软件、GPU 服务器、垂直应用等. 全球科技巨头如 Google, IBM, Microsoft, Facebook 等积极推动 AI 技术生态的自主研发, 抢占人工智能相关产业制高点. 目前人工智能算法、数据、GPU/TPU/NPU 计 算、运行/编译/管理等基础软件已有大量开源资源, 例如 Google 的 TensorFlow、Facebook 的 Torchnet、Microsoft 的 DMTK、IBM 的 SystemML 等. Google、IBM、英伟达、Intel、中国科学院等都在积 极布局人工智能领域的计算芯片. 例如 IBM 的 TrueNorth 芯片模拟人脑神经网络设计 ${ }^{[9]}$, 已具有相 当于包含 6400 万个神经细胞和 160 亿个神经突触的类脑数据处理能力, 并应用于超级计算机和美国 空军.

(4) 人工智能创新创业如火如茶. 全球产业界充分认识到人工智能技术引领新一代科技产业发展 的重大意义, 比如 2017 谷歌 I/O 大会明确提出发展战略从 “Mobile First”转向 “AI First”, 微软 2017 财年年报首次将人工智能作为公司发展愿景. 人工智能领域处于创新创业的前沿, 麦肯锡报告 2016 年

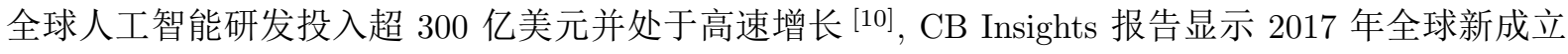
人工智能创业公司 1100 家, 人工智能领域共获得投资 152 亿美元, 同比增长 $141 \%$ [11].

(5) “智能 +” 成为人工智能应用的创新范式. “智能 + ” 创新范式是指人工智能技术向创新性的 消费场景和不同行业快速渗透融合并重塑整个社会发展, 也为人类社会交通、医疗、教育、安防等领 域带来普惠服务, 这是人工智能作为第 4 次技术革命关键驱动力的最主要表现方式. 例如: 智能手机

华为 Mate10 搭载人工智能领域的深度学习芯片; 智能交通—Google 自动驾驶汽车已经在公 路上行驶了 400 万英里; 智能医疗— 2016 年 Google 检测糖尿病诱发的视网膜病变; 智能安防 视频的行人和车辆属性分析技术已经广泛应用于我国公共安全领域的雪亮工程; 等等.

(6) 人工智能加速成为国家战略. 人工智能将成为新一轮产业革命的引擎, 必将深刻影响国际产 业竞争格局和一个国家的国际竞争力. 世界主要发达国家纷纷把发展人工智能作为提升国家竞争力、 维护国家安全的重大战略, 加紧积极谋划政策, 围绕核心技术、顶尖人才、标准规范等强化部署, 力图 在新一轮国际科技竞争中掌握主导权. 例如人工智能成为德国 “工业 4.0”、美国 “工业互联网”、日本 “超智能社会”、“中国制造 2025”等重大国家战略的核心技术. 2017 年 7 月 20 日, 国务院发布了《新 一代人工智能发展规划》, 开启了我国人工智能快速创新发展的新征程 ${ }^{[12]}$.

(7) 人工智能的社会影响得到广泛关注. 2017 年 11 月, Nature 文章 “Four Ethical Priorities for Neurotechnologies and AI" 提出人工智能和脑 - 机接口必须尊重和保护人的隐私、身份认同、能动性 和平等性 ${ }^{[13]} .2017$ 年 1 月, 在美国加州召开 Asilomar 会议, 近千名人工智能和机器人领域的专家联 
合签署了 Asilomar 人工智能 23 条原则 (Asilomar AI principles) ${ }^{1)}$, 呼呼保障人类未来的伦理、利益 和安全. 2018 年, 来自澳大利亚、美国、日本等 30 多个国家和地区的研究人员签署公开信, 敦促韩国 科学技术院停止对 $\mathrm{AI}$ 武器的研发.

(8) 人工智能领域的误解和炒作普遍存在. 由于人工智能与人类智能密切关联且应用前景广阔、 专业性很强, 容易造成人们的误解, 也带来了不少炒作. 例如, 有些人错误地认为人工智能就是机器学 习 (深度学习), 人工智能与人类智能是零和博亦, 人工智能已经达到 5 岁小孩的水平, 人工智能系统 的智能水平即将全面超越人类水平, 30 年内机器人将统治世界, 人类将成为人工智能的奴隶等. 这些 错误认识会给人工智能的发展带来不利影响. 还有很多人对人工智能预期过高, 以为通用智能很快就 能实现, 只要给机器人发指令就可以干任何事. 另外还存在有意地炒作并通过包装人工智能概念来谋 取不当利益.一些地方不切实际一窝蜂发展人工智能产业, “一拥而上、一哄而散” 的跟风行为不利于 人工智能的可持续发展. 因此, 科学家有义务向社会大众普及人工智能知识, 引导政府、企业、民众科 学客观地认识和了解人工智能.

\section{4 人工智能的未来发展趋势}

当前人工智能处于从 “不能用” 到 “可以用” 的技术拐点, 但是距离 “很好用” 还有数据、能耗、 泛化、可解释性、可靠性、安全性等诸多瓶颈, 理论创新和产业应用发展空间巨大. 总体而言, 人工智 能的发展趋势是理论更完备、技术更先进、产业更繁荣、应用更广泛、法规更健全.

(1) 从专用智能到通用智能. 如何实现从狭义或专用人工智能 (弱人工智能, 具备单一领域智能) 向通用人工智能 (强人工智能, 具备多领域智能) 的跨越式发展, 既是下一代人工智能发展的必然趋势, 也是国际研究与应用领域的挑战问题. 2016 年 10 月美国国家科学技术委员会 (The National Science and Technology Commission, NSTC) 发布了《国家人工智能研究与发展战略计划》, 提出在美国的人 工智能中长期发展策略中要着重研究通用人工智能 ${ }^{[14]}$. DeepMind 创始人 Demis Hassabis 提出朝着 “创造解决世界上一切问题的通用人工智能” 这一目标前进; 微软在 2017 年 7 月成立了包括 100 多位 感知、学习、推理、自然语言理解科学家的通用人工智能实验室.

(2) 从机器智能到人机混合智能. 机器智能的一个重要研究方向就是借鉴脑科学和认知科学的研 究成果 ${ }^{[15]}$, 研究从智能产生机理和本质出发的新型智能计算模型与方法, 实现具有脑神经信息处理机 制和类人智能行为与智能水平的智能系统. 在美国、欧盟、日本等国纷纷启动的脑计划中, 类脑智能 已成为核心目标之一 ${ }^{[16]}$. 英国工程与自然科学研究理事会 EPSRC 发布了 “A Strategy Roadmap for Human-like Computing” 并启动类脑智能研究计划.

人机混合智能旨在将人的作用或认知模型引入到人工智能系统中, 提升人工智能系统的性能, 使 人工智能成为人类智能的自然延伸和拓展, 通过人机协同更加高效地解决复杂问题. 人机混合智能得 到了我国新一代人工智能规划、美国脑计划、Facebook 脑机语音文本界面、Elon Musk 人脑芯片嵌入 和脑机接口计划等的高度关注.

(3) 从 “人工 + 智能” 到自主智能系统. 当前人工智能的大量研究集中在深度学习, 但是深度学习 的瓶颈是 “智能” 来自于 “人工”: 人工设计深度神经网络模型、人工设定应用场景、人工采集和标注 大量训练数据、用户需要人工适配智能系统等. 因此已有科研人员开始关注减少人工干预的自主智能 方法, 提高机器智能对环境的自主学习能力. 例如 AlphaZero 从零开始, 通过自我对弯强化学习实现

1) Asilomar AI principles. 2017. https://futureoflife.org/ai-principles/. 
围棋、国际象棋、日本将棋的 “通用棋类 AI” [17]. 在人工智能系统的自动化设计方面, 2017 年谷歌提 出的 AutoML 试图通过自动创建机器学习系统降低 AI 人员成本 ${ }^{[18]}$.

(4) 人工智能产业将蓬勃发展. 随着人工智能技术的进一步成熟以及政府和产业界投入的日益增 长, 全球人工智能产业规模在未来十年将进入高速增长期. 例如, 我国发布的《新一代人工智能发展规 划》就提出到 2030 年, 人工智能核心产业规模超过 1 万亿元, 带动相关产业规模超过 10 万亿元 ${ }^{[12]}$. 人工智能的产业生态构建成为竞争制高点. 在未来的布局中, 谁能够占据人工智能的产业生态, 谁将 在竞争中占据有利地位. 以人工智能模型创新为源头, 以算法、数据和计算开源为途径, 以与领域和行 业的快速渗透和颠覆为呈现的人工智能技术和产业生态将会形成.

(5) 人类将进入普惠型智能社会. “人工智能 $+\mathrm{X}$ ” 的创新模式将随着技术和产业的发展日趋成熟. 人工智能在未来将与社会生产生活的各个行业紧密结合, 将重塑整个社会发展. 我国经济社会转型升 级对人工智能有重大需求, 在消费场景和行业应用的需求牵引下, 需要打破人工智能的感知瓶颈、交 互瓶颈和决策瓶颈, 促进人工智能技术与社会各行各业的融合提升, 建设若干标杆性的应用场景创新, 实现低成本、高效益、广范围的普惠型智能社会.

(6) 人工智能的法律法规将更为健全. 世界各国都将制定完善的人工智能法律法规, 甚至在立法 方面开展合作. 2017 年 9 月, 联合国犯罪和司法研究所 (UNICRI) 决定在海牙成立第一个联合国人工 智能和机器人中心, 规范人工智能的发展. 2018 年 4 月 10 日, 欧洲 25 个国家签署了《人工智能合作 宣言》, 从国家战略合作层面来推动人工智能发展, 确保欧洲人工智能研发的竞争力, 共同面对人工智 能在社会、经济、伦理及法律等方面的机遇和挑战 ${ }^{[19]}$.

(7) 人工智能将成为更多国家的战略选择. 2018 年 3 月 29 日法国发布人工智能发展战略, 旨在推 动法国成为人工智能领域的全球领先国家之一. 俄罗斯总统普京也表示, 掌握人工智能的国家将成为 “世界的统治者”。

(8) 人工智能教育将会全面普及. 国务院《新一代人工智能发展规划》指出要支持开展形式多样 的人工智能科普活动, 全面提高全社会对人工智能的整体认知和应用水平 ${ }^{[12]}$.

\section{5 结论}

人工智能经过 60 多年的发展已取得了重大进展, 但总体上还处于初级阶段. 人工智能既具有巨 大的理论与技术创新空间，也具有广阔的应用前景. 高科技本身没有天使和魔鬼之分, 人工智能亦是 如此. 人工智能这把双刃剑是天使还是魔鬼取决于人类自身. 我们应未雨绸缪, 形成合力, 确保人工智 能的正面效应, 确保人工智能造福于人类.

\section{参考文献}

1 Brundage M, Avin S, Clark J, et al. The malicious use of artificial intelligence: forecasting, prevention, and mitigation. 2018. ArXiv: 1802.07228

2 Silver D, Huang A, Maddison C J, et al. Mastering the game of Go with deep neural networks and tree search. Nature, 2016, 529: 484-489

3 He K, Zhang X, Ren S, et al. Deep residual learning for image recognition. In: Proceedings of the IEEE Conference on Computer Vision and Pattern Recognition, Las Vegas, 2016. 770-778

4 Sun Y, Chen Y H, Wang X G, et al. Deep learning face representation by joint identification-verification. In: Proceedings of the 27th International Conference on Neural Information Processing Systems, Montreal, 2014. 1988-1996

5 Xiong W, Wu L F, Droppo J, et al. The Microsoft 2017 conversational speech recognition system. In: Proceedings of IEEE International Conference on Acoustics, Speech and Signal Processing (ICASSP), Calgary, 2018. 5934-5938 
6 Esteva A, Kuprel B, Novoa R A, et al. Dermatologist-level classification of skin cancer with deep neural networks. Nature, 2017, 542: 115-118

7 Krizhevsky A, Sutskever I, Hinton G E. ImageNet classification with deep convolutional neural networks. In: Proceedings of International Conference on Neural Information Processing Systems, Lake Tahoe, 2012. 1097-1105

8 Silver D, Schrittwieser J, Simonyan K, et al. Mastering the game of Go without human knowledge. Nature, 2017, 550: 354-359

9 Akopyan F, Sawada J, Cassidy A, et al. TrueNorth: design and tool flow of a $65 \mathrm{~mW} 1$ million neuron programmable neurosynaptic chip. IEEE Trans Comput-Aided Des Integr Circ Syst, 2015, 34: 1537-1557

10 McKinsey. McKinsey Quarterly 2016 Number 1: Overview and Full Issue. 2016. https://www.mckinsey.com/businessfunctions/organization/ our-insights/mckinsey-quarterly-2016-number-1-overview-and-full-issue

11 CB Insights. CB Insights Report. 2017. https://www.cbinsights.com/research/artificial- intelligence/

12 中华人民共和国国务院. 新一代人工智能发展规划. 2017. http://www.gov.cn/zhengce/content/2017-07/20/content_ 5211996.htm

13 Yuste R, Goering S, Arcas B A, et al. Four ethical priorities for neurotechnologies and AI. Nature, 2017, 551: 159-163

14 The Networking and Information Technology Research and Development (NITRD). The national artificial intelligence research and development strategic plan. 2016. https://www.nitrd.gov/news/national_ai_rd_strategic_plan.aspx

15 Poo M M, Xu B, Tan T N. Brain science and brain-inspired intelligence technology-an overview. Bull Chin Acad Sci, 2016, 31: 725-736 [蒲慕明, 徐波, 谭铁牛. 脑科学与类脑研究概述. 中国科学院院刊, 2016, 31: 725-736]

16 Zeng Y, Liu C L, Tan T N. Retrospect and outlook of brain-inspired intelligence research. Chin J Comput, 2016, 1: 212-222 [曾毅, 刘成林, 谭铁牛. 类脑智能研究的回顾与展望. 计算机学报, 2016, 1: 212-222]

17 Silver D, Hubert T, Schrittwieser J, et al. Mastering chess and shogi by self-play with a general reinforcement learning algorithm. 2017. ArXiv: 1712.01815

18 Zoph B, Le Q V. Neural architecture search with reinforcement learning. 2017. ArXiv: 1611.01578

19 European Commission. Cooperation on artificial intelligence. 2018. http://ec.europa.eu/ newsroom/dae/document.cfm?doc_id $=50951$

\title{
Artificial intelligence: angel or devil?
}

\author{
Tieniu TAN, Zhenan SUN \& Zhaoxiang ZHANG* \\ Institute of Automation, Chinese Academy of Sciences, Beijing 100190, China \\ * Corresponding author. E-mail: zhaoxiang.zhang@ia.ac.cn
}

\begin{abstract}
Artificial intelligence (AI) achieved important breakthroughs under the joint impetus of an unprecedented volume of data and exponentially growing computing capacities, and therefore became a significant focus of competition among the big powers. Meanwhile, AI showed its transformative impacts on human society and caused increasing public concern as well as considerable controversy. This article tries to draw a realistic panorama of $\mathrm{AI}$ at the macro level, including basic concepts, development history, current situation, and future trends; to reveal an unbiased profile and growing rules; and to develop a scientific perspective and realistic expectations of social knowledge. Finally, the article proposes an initiative to face the potential safety risks and challenges. This requires the strengthening of forward-looking prevention and guidance on restraint, the minimization of risk, and ensuring the safe, positive, and profitable development of AI.
\end{abstract}

Keywords AI development history, AI current situation, AI trends of development, laws and regulations, social ethics 


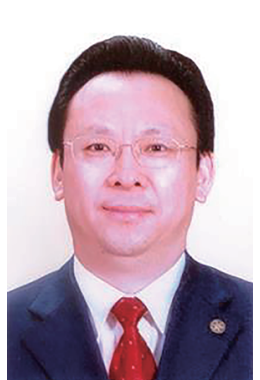

Tieniu TAN received the B.Sc. degree in electronic engineering from Xi'an Jiaotong University, China, in 1984, and the M.Sc. and Ph.D. degrees in electronic engineering from Imperial College, London, U.K., in 1986 and 1989, respectively. $\mathrm{He}$ is currently a professor and the director of the Center for Research on Intelligent Perception and Computing (CRIPAC), and deputy director of the Liaison Office of the Central People's Government in the Hong Kong S.A.R. His current research interests include biometrics, image and video understanding, and information content security. He is a fellow of CAS, The World Academy of Sciences (TWAS) for the advancement of science in developing countries, IEEE, and the International Association of Pattern Recognition (IAPR). His is an international fellow of the UK Royal Academy of Engineering.

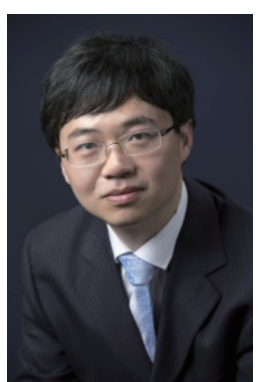

Zhaoxiang ZHANG received the B.S. degree in electronic science and technology from the University of Science and Technology of China, Hefei, China in 2004, and the Ph.D. degree from the National Laboratory of Pattern Recognition, Institute of Automation, Chinese Academy of Sciences, Beijing, China, in 2009. In 2009, he joined the School of Computer Science and Engineering, Beihang University, Beijing, as an assistant professor from 2009 to 2011, an associate professor from 2012 to 2015, and the vicedirector of the Department of Computer Application Technology from 2014 to 2015 . In 2015, he returned to the Institute of Automation, Chinese Academy of Sciences, as a full professor. His current research interests include computer vision, pattern recognition, machine learning, and brain-inspired neural network and brain-inspired learning. Dr. Zhang has been an associate editor or guest editor of internal journals such as Neurocomputing, Pattern Recognition Letters, and IEEE ACCESS.

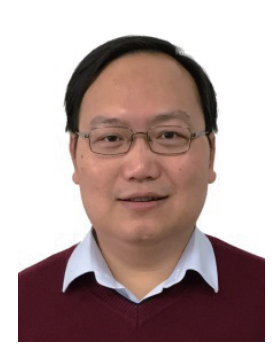

Zhenan SUN received the B.E. degree in industrial automation from the Dalian University of Technology, China, the M.S. degree in system engineering from Huazhong University of Science and Technology, China, and the Ph.D. degree in pattern recognition and intelligent systems from CASIA in 1999 2002, and 2006, respectively. $\mathrm{He}$ is currently a professor in the Center for Research on Intelligent Perception and Computing, National Laboratory of Pattern Recognition, Institute of Automation, Chinese Academy of Sciences, China. His research interests include biometrics, pattern recognition, and computer vision. He is a fellow of the IAPR. 